Journal of Social and Development Sciences

Vol. 1, No. 2, pp. 67-73, Mar 2011

\title{
Corruption and Inflation Tax in the Middle East and North Africa (MENA) Region: Sensitivity to Definition of Corruption
}

\author{
*Ahmad Jafari Samimi, Maryam Abedini \\ Islamic Azad University of Firozkuh Branch, Firozkuh, Iran \\ *jafarisa@yahoo.com
}

\begin{abstract}
Corruption usually harms all aspects of macroeconomic performances of all countries around the World especially the developing world. The purpose of the present paper is to investigate the impact of corruption on inflation tax in MENA countries. In a previous paper ${ }^{1}$, we used Corruption Perception Index (CPI) as a definition of corruption and applied Friedman, International Bank and Vito Tanzi definitions for inflation tax. We concluded that, there is a positive and significant relationship between corruption and inflation tax. In this paper, we used two different indices for corruption; Corruption Perception Index (CPI) and Control of Corruption Index (CCI) to investigate the sensitivity to different definition of corruption. To do so, we have concentrated on a sample of 17 developing countries from Middle East and North Africa countries for which the necessary data were available for the period 2003-2008. We have used two different indices for corruption; Corruption Perception Index (CPI) and Control of Corruption Index (CCI). Our findings based on panel data (we used unbalanced panel data because of missing data) regression models indicate that in general a positive relationship between corruption and inflation tax exists. In other words, the higher is the corruption the higher will be the inflation tax. Therefore, according to the results, governments have to try to use policies reducing corruption.
\end{abstract}

Key Words: Corruption Perception Index (CPI), Control of Corruption Index (CCI), Inflation tax, Panel data.

\section{Introduction and Literature}

In recent years, and especially in the 1990s, a phenomenon broadly referred to as corruption has attracted a great deal of attention. In countries developed and developing, large or small, market-oriented or otherwise, governments have fallen because of accusations of corruption, prominent politicians (including president of countries and prime ministers) have lost their official positions, and, in some cases, whole political classes have been replaced. Corruption is not a new phenomenon. Two thousand years ago, Kautilya, the Corruption, defined as the misuse of public office for private gain, has attracted a great deal of attention in recent years. Many international and regional organizations now regard corruption as major obstacles to good policy making. The ways in which corruption can manifest and impact on the economy are many and varied, and it is important to understand the range and diversity of the mechanisms involved. In this paper we present a theoretical and empirical analysis of a mechanism that relates to considerations. The general relationship between corruption and inflation tax has been identified in some empirical studies indirectly (Blackburn, Neanidis and Haque, 2009). These and other investigations (including theoretical work) also provide insight into the many channels through which corruption might take effect.

A non-exhaustive list of these is the following: corruption may cause a misallocation of talent and skills away from productive (entrepreneurial) activities (Acemoglu, 1995) corruption may undermine the protection of the property rights, create obstacles to doing business and impede innovation and technological transfer (Hall and Jones, 1999; North, 1990) corruption may cause firms to expand less rapidly, to adopt inefficient technologies and to shift their operations to the informal sector (Svensson, 2005) corruption may limit the extent of a country' trade openness and reduce inflows of foreign investment (Pellegrini and Gerlagh, 2004; Wei, 2000); corruption may lead to costly concealment and detection of illegal income, resulting in a deadweight loss of resources (Blackburn et al. 2006; Blackburn and Forgues-Puccio, 2007); corruption may 
compromise human development through a deterioration in the scale and quality of public health and education programs (Blackburn and Sarmah, 2008; Gupta et al. 2000; Reinikka and Svensson, 2005) and corruption may cause a general misallocation of public expenditures as certain areas of spending (military spending) are targeted more for their capacity to generate bribes than their potential to improve living standards (Gupta et al. 2001; Mauro, 1995; Tanzi and Davoodi, 1997).

In terms of public finances, corruption may impact independently on both the expenditure and revenue sides of the government' s budget: for any given state of the latter, corruption can distort the composition of expenditures in ways described above; for any given state of the former, corruption can alter the manner by which revenues must be generated, as suggested by other empirical evidence. Thus Ghura (1998), Imam and Jacobs (2007) and Tanzi and Davoodi $(1997,2000)$ conclude that corruption reduces total tax revenues by reducing the revenues from almost all taxable sources (including incomes, profits, property, capital gains and goods and services.) The implication is that, ceteris paribus, other means of raising income must be sought, and one of the most tempting of these is seigniorage. Significantly, it has been found that inflation (a likely consequence of seignior age) is positively related to the incidence of corruption (Al-Marhubi 2000). It is these observations that provide the motivation for this paper which seek to analyze in detail the influence of corruption on the composition of government revenues and government's expenditures, especially nonproductive government expenditures, and the implications of this for inflation tax.

The theory of optimal taxation (Phelps, 1973) contends that the government tries to equate the marginal cost of inflation tax with the marginal cost of output taxes in order to minimize the distortions of taxation. Therefore, the government may choose to use seignior age as a way to finance public expenditures and budget deficit. When there is possible for the government to use seignior age to finance government expenditures and budget deficit, it is easier to increase government expenditures compared with the situation that government has to raise taxes to finance government expenditures. Governments, especially in developing countries, try to obtain revenue from printing money by creating inflation as a way to finance budget deficit. Inflation and money supply growth are higher when central banks are less independent (Alesina and Summers, 1997). Alesina and Perotti (1995) discuss the political economy of budget deficit. Fischer et al. (2002) discuss the effect of budget deficit, seignior age and some other determinants of modern hyper and high inflations. Although seignior age can explain the high rates of inflations in many developing countries, but it does not analyze the underlying forces that are behind budget deficit and inflation while they are not socially favorable. Corruption provides the economics of budget deficit through increasing government expenditure especially non-productive government expenditure.

\section{Model, Data, and Estimation Methodology}

We study the case of 17 developing countries (MENA) and use annual data for the 2003- 2008. The time period and frequently is largely dictated by the availability of data. Data on $I T$ is the ratio of inflation tax to GDP (percent). SFT is the ratio of foreign trade (export plus import to GDP). PGDP is GDP per capita and $I N$ is the inflation that all of them are from WDI ${ }^{1}$. We have also used two different indices for corruption; the first one is Corruption Perception Index (CPI) that is an e-index based on 17 different types of votes by 10 organizations that are from transparency international organization; and the second one is Control of Corruption Index (CCI) that oriented from WGI ${ }^{2}$. Corruption Perception Index range is between zero and 10 that zero shows the maximum amount of corruption and 10 shows the minimum amount of corruption in the country; because of this contradiction, we minus all of the scores from 10 , so the higher scores represent the maximum amount of corruption and the lower scores show the minimum amount of corruption. Control of Corruption Index range is between -2.5 and 2.5 that higher scores represent an economy with more control of corruption and lower scores show an economy with less control of corruption. The basic model is estimated on panel data for 17 developing countries from Middle East and North Africa and the sample period is 20032008.

$I T_{i t}=C_{i t}+\beta_{1} S F T_{i t}+\beta_{2} L O G\left(P G D P_{i t}\right)+\beta_{3} \operatorname{COR} R_{i t}+\beta_{4} I N_{i t}+\beta_{5}[I T]_{-1_{i t}^{-}}+\beta_{6}[\operatorname{CORR} * D U M]_{i t}+\varepsilon_{i t}$

1-World Development Indicators.

2-World Governance Indicators. 
Where;

$i=$ time.

$t=$ country.

$I T=$ ratio of inflation tax to GDP.

$S F T=$ ratio of foreign trade to GDP.

$P G D P=$ GDP per capita.

CORR $=$ corruption index.

$I N=$ inflation.

$[I T]_{-1}=$ ratio of inflation tax to GDP with one lag.

$D U M=$ dummy variable.

$\beta_{1}, \beta_{2}, \ldots, \beta_{6}$ are parameters in the model and $\varepsilon_{i t}$ is error term.

\section{Results and Discussion}

First, we use Levin, Lin, Chu unit root test to test the stationary for variables. The results, as represent in table 1 , show that all of the variables are station.

Table 1: The results related to stationary test for dependent variable.

\begin{tabular}{ccc}
\hline Variable & Statistic test & Unit root test result \\
\hline $\mathbf{I T}_{\mathrm{F}} \mathbf{1}$ & -13.97 & stable \\
$\mathbf{I T}_{\mathrm{IB}^{2}}$ & -6.43 & stable \\
$\mathbf{I T}_{\mathrm{V}}{ }^{3}$ & -5.88 & stable \\
\hline
\end{tabular}

Source: Researcher calculations using Eviews 6.

Table 2: The results related to stationary test for independent variables.

\begin{tabular}{lcc}
\hline Variable & Statistic test & Unit root test result \\
\hline LOG(PGDP) & -1.6 & stable \\
SFT & -4.2 & stable \\
CORR(CPI) & -3.2 & stable \\
CORR(CCI) & -3.1 & stable \\
IN & -3.7 & stable \\
{$\left[\mathrm{IT}_{\mathrm{F}}\right]_{-\mathbf{1}^{4}}$} & -12.7 & stable \\
{$\left[\mathrm{IT}_{[\mathrm{IB}}\right]_{-\mathbf{1}^{5}}$} & -5.1 & stable \\
{$\left[\mathrm{IT}_{\mathrm{V}}\right]_{-\mathbf{1}^{6}}$} & -7.9 & stable \\
\hline
\end{tabular}

Source: Researcher calculations using Eviews 6.

Second, we test heterogeneous between units by F-statistic. If null hypothesis is not accepted, we use panel data. Null hypothesis is:

$\mathrm{H}_{0}: \mu_{1}=\mu_{2}=\cdots=0$

$\mathrm{H}_{0} \neq \mathrm{H}_{1}$

$F=\frac{\frac{(\text { RRSS-URSS })}{(N-1)}}{\frac{(N S S S}{(N T-N-K)}} \sim F[(N-1) .(N T-N-K)]$

1- Ratio of inflation tax to GDP (Friedman definition).

2- Ratio of inflation tax to GDP (International Bank definition).

3- Ratio of inflation tax to GDP (Vitotanzi definition).

4- Ratio of inflation tax to GDP with one lag (Friedman definition).

5- Ratio of inflation tax to GDP with one lag (International Bank definition).

6- Ratio of inflation tax to GDP with one lag (Vitotanzi definition). 
RRSS $=$ Restrict Residual Sum Squares.

URSS = Unrestricted Residual Sum Squares.

$N=$ number of units.

$K=$ number of parameters.

Then for choice between Fixed Effect (F.E) and Random Effect (R.E) models we used Hausman Test: $H=\left(b_{s}-B_{s}\right)\left(M_{1}-M_{0}\right)^{-1}\left(b_{g}-B_{g}\right) \approx X^{2}(r)$

Where $r=$ number of parameters, $M_{1}=$ covariance matrix for coefficient of F.E model $\left(b_{s}\right)$.

In Hausman test null hypothesis show Fixed Effect. In according above test, as shows in table 1, we run some of the regressions with Random Effect test and some of them with Fixed Effect test.

Tabel3: Model's regression findings

\begin{tabular}{|c|c|c|c|c|c|c|}
\hline Variable & $\begin{array}{c}\text { Equation } \\
\text { (1) }\end{array}$ & $\begin{array}{c}\text { Equation } \\
\text { (2) }\end{array}$ & $\begin{array}{c}\text { Equation } \\
\text { (3) }\end{array}$ & $\begin{array}{c}\text { Equation } \\
\text { (4) }\end{array}$ & $\begin{array}{c}\text { Equation } \\
\text { (5) }\end{array}$ & $\begin{array}{c}\text { Equation } \\
\text { (6) }\end{array}$ \\
\hline \multirow[t]{2}{*}{ C } & .00017 & $* * *-22$ & .01 & $* * .0006$ & $* * *-.27$ & -.007 \\
\hline & $(.46)$ & $(-3.4)$ & $(1.7)$ & (2.3) & $(-9.3)$ & $(-1.17)$ \\
\hline \multirow[t]{2}{*}{ SFT } & $* * .00015$ & $* * * .1$ & $* * * .008$ & $* .00009$ & ***.09 & $* * * .004$ \\
\hline & $(2.1)$ & (3.9) & (6.1) & $(1.6)$ & $(6.9)$ & $(2.9)$ \\
\hline \multirow[t]{2}{*}{ LOG(PGDP) } & $*_{-.00003}$ & $* * * .03$ & -.0007 & -.00002 & $* * * .03$ & .0003 \\
\hline & $(-1.6)$ & (3.6) & $(-.68)$ & $(-.92)$ & (13.1) & $(-.53)$ \\
\hline \multirow[t]{2}{*}{ CORR(CPI) } & .00008 & -.002 & $* *{ }_{-} .001$ & & & \\
\hline & $(2.3)$ & $(-.76)$ & $(-3.4)$ & & & \\
\hline CORR(CCI) & & & & $\begin{array}{c}* *-.0001 \\
(-2.07)\end{array}$ & $\begin{array}{c}-.02 \\
(-1.09)\end{array}$ & $\begin{array}{c}{ }^{* *} .002 \\
(2.1)\end{array}$ \\
\hline \multirow[t]{2}{*}{ IN } & -.00001 & .0007 & ***.001 & -.00001 & .001 & $* * * .001$ \\
\hline & $(-.91)$ & $(.95)$ & (26.9) & $(-.92)$ & (1.32) & (14.07) \\
\hline \multirow[t]{2}{*}[\mathrm{IT}_{\mathrm{F}}]{$_{-1}$} & ***.018 & & & $* * * .18$ & & \\
\hline & (13.3) & $* * * 28$ & & (14.1) & $* * * 27$ & \\
\hline$\left[\mathrm{IT}_{\mathrm{IB}}\right]_{-1}$ & & $(3.3)$ & & & $(2.9)$ & \\
\hline$\left[\mathrm{IT}_{\mathrm{V}}\right]_{-1}$ & & & $\begin{array}{c}.11 \\
(1.23)\end{array}$ & & & $\begin{array}{l}* * .012 \\
(2.28)\end{array}$ \\
\hline CORR(CPI)*DUM & $\begin{array}{c}-.00001 \\
(-1.1)\end{array}$ & $\begin{array}{l}.00005 \\
(.003)\end{array}$ & $\begin{array}{l}*-.009 \\
(-1.9)\end{array}$ & & & \\
\hline CORR(CCI)*DUM & & & & $\begin{array}{c}.0002 \\
(.76)\end{array}$ & $\begin{array}{l}-.46 \\
(-1.6)\end{array}$ & $\begin{array}{l}* * * .26 \\
(-3.7)\end{array}$ \\
\hline $\mathrm{R}^{2}$ & .37 & .94 & .97 & .36 & .96 & .97 \\
\hline $\bar{R}^{2}$ & .31 & .92 & .96 & .3 & .94 & .96 \\
\hline D.W & 1.89 & 2 & 2 & 1.89 & 1.92 & 1.87 \\
\hline$F_{\text {test }}{ }^{1}$ & 1.91 & 4.5 & 7.1 & 1.99 & 4.4 & 1.87 \\
\hline $\mathbf{H}_{\text {test }^{2}}{ }^{2}$ & 6.53 & 55.2 & 33.05 & 6.85 & 59.5 & 31.5 \\
\hline$H_{\text {test }}$ result & R.E. ${ }^{3}$ & F.E. 4 & F.E. & R.E. & F.E. & F.E. \\
\hline $\mathbf{N}$ & 79 & 79 & 79 & 79 & 79 & 79 \\
\hline
\end{tabular}

Source: Researcher calculations using Eviews 6.

*,**\&** respectively significant in $10 \%, 5 \% \& 1 \%$ level.

The numbers in the parentheses show t-statistic.

1-Redundant Fixed Effect Test

2-Correlated Random Effects-Hausman Test

3-Random Effect

4-Fixed Effect 
According to equation 1, Friedman inflation tax definition and Corruption Perception Index (CPI) have been applied. Based on regression results in this column, the estimated parameters coefficient of CORR in equation 1 is positive and significant. The coefficient of the ratio of foreign trade to GDP (SFT), is positive and significant. GDP per capita (PGDP) is negative and significant. The coefficient of inflation (IN) is negative and it is not significant. The coefficient of the ratio of inflation tax with a lag $\left(\left[\mathrm{IT}_{\mathrm{F}}\right]_{-1}\right)$ is positive and significant.

The coefficient of Dummy variable is negative but it is not significant. To understand the difference between Iran's performance and the average of other countries, we have to plus the coefficient of Dummy variable with the coefficient of corruption index. If the result is near the coefficient of corruption index, means that any difference cannot be seen between Iran's performances in comparison with other countries; and if the result is far from the coefficient of corruption index, means that a significant difference between Iran's performance and other countries can be seen. For this respect, the result shows that the relationship between corruption and inflation tax, in Iran, would not have a significant difference in comparison with the average of other countries.

According to equation 2, International Bank inflation tax definition and Corruption Perception Index (CPI) have been applied. Based on regression results in this column, the estimated parameters coefficient of Corruption (CORR) in equation 2 is negative but it is not significant. The coefficient of the ratio of foreign trade to GDP (SFT), is positive and significant. GDP per capita (PGDP) is positive and significant. The coefficient of inflation (IN) is positive but it is not significant. The coefficient of the ratio of inflation tax with a $\operatorname{lag}\left(\left[\mathrm{IT}_{\mathrm{IB}}\right]_{-1}\right)$ is positive and significant. According to the coefficient of Dummy variable and the coefficient of corruption index, the relationship between corruption and inflation tax, in Iran, would not have a significant difference in comparison with the average with the average of other countries; but, the increase in corruption contributed to decrease in inflation tax. According to equation 3, Vitotanzi inflation tax definition and Corruption Perception Index (CPI) have been applied. Based on regression results in this column, the estimated parameters coefficient of Corruption (CORR) in equation 3 is negative and significant. The coefficient of the ratio of foreign trade to GDP (SFT), is positive and significant. GDP per capita (PGDP) is negative and it is not significant. The coefficient of inflation (IN) is positive and significant. The coefficient of the ratio of inflation tax with a lag $\left(\left[\mathrm{IT}_{\mathrm{V}}\right]_{-1}\right)$ is positive but it is not significant. According to the coefficient of Dummy variable and the coefficient of corruption index, the relationship between corruption and inflation tax, in Iran, would not have a significant difference in comparison with the average of other countries; but, the increase in corruption contributed to decrease in inflation tax.

According to equation 4, Friedman inflation tax definition and Control of Corruption Index (CCI) have been applied. Based on regression results in this column, the estimated parameters coefficient of Corruption (CORR) in equation 4 is negative and significant, so the more increase at controlling of the corruption in a country, will contribute to less inflation tax. The coefficient of the ratio of foreign trade to GDP (SFT), is positive and significant. GDP per capita (PGDP) is negative and it is not significant. The coefficient of inflation (IN) is negative and it is not significant. The coefficient of the ratio of inflation tax with a lag $\left(\left[\mathrm{IT}_{\mathrm{F}}\right]_{-1}\right)$ is positive and significant. According to the coefficient of Dummy variable and the coefficient of corruption index, the relationship between corruption and inflation tax, in Iran, would not have a significant difference in comparison with the average of other countries. According to equation 5, International Bank inflation tax definition and Control of Corruption Index (CCI) have been applied. Based on regression results in this column, the estimated parameters coefficient of Corruption (CORR) in equation 5 is negative but it is not significant. The coefficient of the ratio of foreign trade to GDP (SFT), is positive and significant. GDP per capita (PGDP) is positive and significant. The coefficient of inflation (IN) is positive but it is not significant. The coefficient of the ratio of inflation tax with a lag $\left(\left[\mathrm{IT}_{\mathrm{IB}}\right]_{-1}\right)$ is positive and significant. According to the coefficient of Dummy variable and the coefficient of corruption index, the relationship between corruption and inflation tax, in Iran, would have a significant difference in comparison with the average of other countries.

According to equation 6, Vitotanzi inflation tax definition and Control of Corruption Index (CCI) have been applied. Based on regression results in this column, the estimated parameters coefficient of Corruption (CORR) in equation 6 is positive and significant. The coefficient of the ratio of foreign trade to GDP (SFT) is 
positive and significant. GDP per capita (PGDP) is negative and it is not significant. The coefficient of inflation (IN) is positive and significant. The coefficient of the ratio of inflation tax with a lag $\left(\left[\mathrm{IT}_{\mathrm{V}}\right]_{-1}\right)$ is positive and significant. According to the coefficient of Dummy variable and the coefficient of corruption index, the relationship between corruption and inflation tax, in Iran, would have a significant difference in comparison with the average of other countries.

\section{Conclusion}

Corruption can be effective in creation of inflation tax through budget deficit. The results show that, in MENA countries, the more increase at corruption will lead to more inflation tax and also the more control of corruption will contribute to less inflation tax. So a positive and significant relationship between corruption and inflation tax, in general, have been existed in the countries under consideration. Accordingly to our results, in some cases, a negative relationship between corruption and inflation tax have been seen; that is because of the increasing in government expenditures, especially non-productive government expenditures, and insufficient tax revenues to finance them. In addition, the effectiveness of inflation tax from Control of Corruption Index is more than Corruption Perception Index. Also, corruption is sensitive to different definition of inflation tax. As a consequence, more investigation over different period and more countries have been suggested.

\section{References}

Acemoglu, D. (1995). Reward Structures and the Allocation of Talent. European Economic Review, 39: 17-33.

Alesina, A., and Summers, L. (1993). Central Bank Independence and Macroeconomic Performance: Some Comparative Evidence. Journal of Money, Credit and Banking, 25(2), 151-162.

Alesina, A. and Perotti, R. (1995). The Political Economy of Budget Deficits. IMF Staff Papers, 42: 1-31.

Al-Marhubi, F. A. (2002). Corruption and Inflation. Economic Letters, 66: 199-202.

Blackburn, K., Bose, N. and Haque. E.M. (2006). The Incidence and Persistence of Corruption in Economic Development. Journal of Economic Dynamics and Control, 30: 2447-2467.

Blackburn, K., and Forgues-Puccio. G. F. (2007). Distribution and Development in a Model of Misgovernance. European Economic Review, 51(6), 1534-1563.

Blackburn, K. and Sarmah, R. (2008). Corruption, Development and Demography. Economics of Governance, 9: 341-362.

Blackburn, K., Neanidis, C. K. and Haque, M. (2009). Corruption, Seignorage and Growth: Theory and Evidence. Center of Growth and Business Cycles Research, Economic Studies, University of Manchester.

Fischer, S., Sahay, R. and Vegh, C. (2002). Modern Hyper and High Inflations. Journal of Economic Literature, 40(3): 837-880.

Ghura, D. (1998). Tax Revenue in Sub-Saharan Africa: Effect of Economic Policies and Corruption. Working Paper No.135, International Monetary Fund.

Gupta, S., de Mello, L., Sharan, R., (2001). Corruption and Military Spending. European Journal of Political Economy, 17: 749-777.

Gupta S., Davoodi, H. and Tiongson E. (2000). Corruption and the Provision of Health Care and Education Services. IMF Working Paper, 00/116.

Hall, E. R. and Jones, I. C. (1999). Why Do Some Countries Produce So Much More Output Per Worker Than Others? The Quarterly Journal of Economics, 114(1): 83-116.

Imam, P. A. and Jacobs, D. F. (2007). Effect of Corruption on Tax Revenues in the Middle East. Working Paper No. 270, International Monetary Fund.

Mauro, P. (1995). Corruption and Growth. The Quarterly Journal of Economics, 110(3): 681-712.

North, D. C. (1990). Institutions, Institutional Change, and Economic Performance, Cambridge: Cambridge University Press.

Pellegrini, L., and Gerlagh, R. (2004). Corruption's Effect on Growth and its Transmission Channels. Kyklos, 57(3): 429-456.

Phelps, E. (1973). Inflation in the Theory of Public Finance. Swedish Journal of Economics, 75: 67-82. 
Reinikka, R., and Svensson, J. (2005). Fighting Corruption to Improve Schooling: Evidence from a Newspaper Campaign in Uganda. Journal of European Economic Association, 3: 259-267.

Svensson, J. (2005). Eight Questions about Corruption. Journal of Economic Perspectives, 19(3): 19-42.

Tanzi, V., and Davoodi. H. R. (2000). Corruption, Growth, and Public Finances. Working Paper No. 182, International Monetary Fund.

Tanzi, V., and Davoodi. H. R. (1997). Corruption, Public Investment, and Growth. Working Paper No. 139, International Monetary Fund.

Wei, S. (2000). How Taxing is Corruption on International Investors?" Review of Economics and Statistics, 82: 1-11. 